\title{
Castor bean (Ricinus communis L.) as a potential environmental bioindicator
}

\author{
M.G. Mendes, C.D. Santos Junior, A.C.C. Dias and A.M. Bonetti \\ Laboratório de Genética, Instituto de Genética e Bioquímica, \\ Universidade Federal de Uberlândia, Uberlândia, MG, Brasil \\ Corresponding author: M.G. Mendes \\ E-mail: marianagoncalves2004@yahoo.com.br
}

Genet. Mol. Res. 14 (4): 12880-12887 (2015)

Received June 1, 2015

Accepted August 24, 2015

Published October 21, 2015

DOI http://dx.doi.org/10.4238/2015.October.21.8

\begin{abstract}
Biomonitoring of air quality using living organisms is a very interesting approach to environmental impact assessment. Organisms with a vast distribution, such as plants, are widely used for these purposes. The castor bean (Ricinus communis L.) is an oleaginous plant that can potentially be used as a bioindicator plant owing to its rapid growth and large leaves, which have a wide surface area of contact with the air and the pollutants therein. This study investigated the the bioindicator potential of the castor bean by performing several tests. We observed statistically significant differences in the concentrations of chlorophyll $a$ and $b$ in the leaves of plants in polluted areas compared to that in the control group plants, which were located in a pollution-free area. Leaves of plants in the former group had higher peroxidase activity and showed a greater buffering ability than those of plants in the control group. The pKa values obtained via buffering capacity tests, revealed the presence of aminoazobenzene (an industrial dye) in leaves of $R$. communis. Genotoxicity was evaluated through the comet assay technique and revealed that other than some differences in DNA fragmentation, there is no statistically significant difference in this parameter between places analyzed. Our data indicate that $R$. communis can be a highly useful biological indicator. Further, we hypothesized that
\end{abstract}


the castor bean can be a potential candidate for phytoremediation owing its physiological buffering capacity when exposed to substantial pollution.

Key words: Biomonitoring; Buffering capacity; Comet assay;

Peroxidase activity; Photosynthetic pigments; Potential phytoremediator

\section{INTRODUCTION}

Ricinus communis, popularly known as the castor bean, is an oleaginous plant from the family Euphorbiaceae (Popova and Moshkin, 1986; Azevedo et al., 1998). In Brazil, the castor bean is grown in many different regions with great variation in growth habits, stem color, leaves, and racemes (Azevedo and Lima, 2001).

Recently, using living organisms as an auxiliary method for the detection of changes in environment quality has become popular and useful. Vegetables have been widely used as a bioindicator because they tipically show changes in their leaves, growth rates and flowering time, which can be easily identified complementing the environmental monitoring processes of contaminants in the atmosphere (Carneiro and Takayanagui, 2009). R. communis has potential to be an asset to biomonitoring due to its rapid growth and the large leaves, which facilitate pollution detection well, making it an excellent choice as a living biosensor of environmental quality (Kammerbauer and Dick, 2000).

This study aims to assess the potential of the castor bean to be a bioindicator through examining the diverse parameters of its physiology, which are influenced by environmental pollution. Several methodologies were used to evaluate this plant as a bioindicator of air quality, including comet assay, peroxidase activity, photosynthetic pigment evaluation, and leaf buffering capacity (Kammerbauer and Dick, 2000; Tice et al., 2000; Schulz et al., 2008).

\section{MATERIAL AND METHODS}

Leaves of $R$. communis were collected in the early morning (7:00 am to 8:30 am), from random plants in different areas of Uberlândia (18 $\left.52^{\prime} 34^{\prime \prime S}-48^{\circ} 15^{\prime} 21^{\prime \prime W}\right)$, Minas Gerais, Brazil. Samples were collected from five locations according to the relative pollution levels present at each location (Table 1). From each sample site, 7 plants were randomly collected and 9 leaves were picked from each plant, resulting in a total of 63 leaves per location. The collected leaves were stored until needed at $80^{\circ} \mathrm{C}$ in an Ultra freezer (SANYO ${ }^{\circ}$ North American Corporation, San Diego, E.U.A.) (Ayres et al., 2007).

\begin{tabular}{lll}
\multicolumn{2}{c}{ Table 1. Sites with high pollution levels for sample collection. } \\
\hline Site code & Geographic Coordinates & Location data \\
\hline Point 1 & $\mathrm{~S} 18^{\circ} 53^{\prime} 68^{\prime \prime}$ & Next to BR 050 highway. \\
& W $48^{\circ} 16^{\prime} 22^{\prime \prime}$ & \\
Point 2 & $\mathrm{~S} 18^{\circ} 52^{\prime} 68^{\prime \prime}$ & Transport companies, intense traffic of trucks, buses and other diesel vehicles. \\
& W $48^{\circ} 16^{\prime} 39^{\prime \prime}$ & \\
Point 3 & $\mathrm{~S} 18^{\circ} 53^{\prime} 69^{\prime \prime}$ & Between BR 365 and 452 highways \\
Point 4 & W $48^{\circ} 16^{\prime} 22^{\prime \prime}$ & Next the highways BR 050 and BR 365 , near Umuarama. \\
Point 5 (Control) & $\mathrm{S} 18^{\circ} 53^{\prime} 11^{\prime \prime}$ & \\
& W $48^{\circ} 15^{\prime} 76^{\prime \prime}$ & Less urbanized area and the plants are in a preserved Cerrado zone. \\
\hline
\end{tabular}


The genotoxic effects of pollution in $R$. communis leaves was analyzed by comet assay using weighed and macerated leaf samples. The cells were isolated with a cellulase solution (SIGMA-Aldrich, $20 \mathrm{mg} / \mathrm{mL}$ ) at a proportion of $2: 1(\mathrm{w} / \mathrm{v})$, in a water bath (Thermomix BM) at $65^{\circ} \mathrm{C}$ for $1 \mathrm{~h}$. To prepare microscope slides, horizontal electrophoresis, neutralization, and drying were performed as described by Huachaca (2002) with minor modifications. Immediately before analysis, slides were stained with an ethidium bromide solution $(20 \mu \mathrm{g} / \mathrm{mL})$. Slide analyses was performed at The Laboratory of Image Analysis at Federal Uberlândia University. Nucleoids were identified and analyzed using a Carl-Zeiss, confocal microscope with a CHS2 excitation filter of 585-628 nm, barrier filter of $543 \mathrm{~nm}$, at 400X magnification. We analyzed 50 nucleoids per site, code-blind, in a random vision field. The images were obtained by Start LSM Image Browser software directly connected to the microscope. Images were analyzed using the imaging system, TriTek CometScore ${ }^{\mathrm{TM}}$ v 1.5 Freeware. Parameters selected for analysis were \%DNA in the head, $\% D N A$ in the tail, tail length and tail moment. Average measurement values of these parameters were taken for each individual collected. Cell analyses were performed according to comet classes determined, namely, Class I (no tail), Class II (tail length less than $25 \%$ of the diameter of the head), Class III (tail length between $25 \%$ and $100 \%$ of the diameter of the head), Class IV (with tail length greater than that of the head), and Class $\mathrm{V}$ (low definition of comets with very small head) as described elsewhere (Freitas, 2007; Schulz et al., 2008).

Peroxidase activity, an indicator of oxidative stress, was analyzed with the methodology described by Oliveira et al. (2008), with adaptations. Absorbance was read using a microplate reader for 96 wells (Microplate) at $492 \mathrm{~nm}$; each reading was taken twice with a 2-min gap between readings. Peroxidase activity is defined as the variation of absorbance. The effects of pollution on the photosynthetic pigments of the leaves of $R$. communis were explored using a methodology described by Santos (2004). We macerated $2 \mathrm{~g}$ of leaves in liquid nitrogen and transferred these samples to fresh test tubes. The test tubes had been previously wrapped in sheets of aluminum foil to avoid photodegradation. To extract the leaf pigments, $15 \mathrm{~mL}$ acetone was added to $80 \%$ of each tube, and they were then stored at $4^{\circ} \mathrm{C}$ for $72 \mathrm{~h}$. After this period, $1 \mathrm{~mL}$ of each tube was used to determine absorbance rates using a spectrophotometer (Bel Photonics LGS 53) at $645 \mathrm{~nm}$ (chlorophyll a), $663 \mathrm{~nm}$ (chlorophyll $b$ ) and $470 \mathrm{~nm}$ (chlorophyll $c$ and carotenoids) wavelengths. The concentration of chlorophyll $a(1)$, chlorophyll $b(2)$, chlorophyll $c$ and carotenoids pigments (3) were calculated to $\mu \mathrm{g} / \mathrm{mL}$ according to equations described by Lichtenhauer (1987).

$$
\begin{array}{cc}
\mathrm{Ca}=\text { 12.25 Abs663nm + 2.79 Abs645nm } & \text { (Equation 1) } \\
\mathrm{Ca}=21.5 \mathrm{Abs645nm}+5.10 \mathrm{Abs663nm} & \text { (Equation 2) } \\
\mathrm{C}(\mathrm{x}-\mathrm{c})=(1000 \mathrm{Abs} 470 \mathrm{~nm}-1.82 \mathrm{Ca}-85.02 \mathrm{Cb}) / 198 & \text { (Equation 3) }
\end{array}
$$

The effects of pollution on the leaves were analyzed using a buffering capacity test where we prepared a $1.5 \%(\mathrm{w} / \mathrm{v})$ aqueous leaf extract. The $\mathrm{pH}$ was measured with a $\mathrm{pH}$ meter (Tecnopon). Aliquots of $1.0 \mathrm{~mL}$ were added to $0.01 \mathrm{~N} \mathrm{HCl}$ solution (correction factor: 1.74) until the solution reached $\mathrm{pH} 4.0$, and other aliquots of $5.0 \mathrm{~mL} \mathrm{HCl}$ were added until the $\mathrm{pH}$ reached 2.5. For each addition of $\mathrm{HCl}$, the $\mathrm{pH}$ was recorded for later analysis (Kammerbauer and Dick, 2000). To investigate the interference of gaseous pollutants with the buffering capacity of leaves, we analyzed the acid dissociation constants ( $\mathrm{pKa}$ ) from the values in the $\mathrm{pH}$ titration with $\mathrm{HCl}$. The $\mathrm{pKa}$ allowed 
us to identify acids and other substances that had accumulated on the leaves and analyze whether these are related to greenhouse gases such as carbon dioxide, methane, perfluorocarbons, nitrous oxide and hydrofluorocarbons (CFCs) Thereafter, we could determine the influence of pollutants on plants' buffering capacity at each area (Kammerbauer and Dick, 2000).

We used the ANOVA test followed by the Tukey test to check the differences among the data with the aid of the software Bioestat 5.0 (Ayres et al., 2007) in each test.

\section{RESULTS}

\section{Genotoxicity test: comet assay or single cell electrophoresis (SCE)}

The percentage of DNA present in the tail, head, tail length and tail moment (determined by the percentage of DNA in the tail multiplied by the distance between the head and tail) represent the fragmentation or damage done to DNA of the plants of the different tested areas. The results presented in Table 2 show no statistically significant difference between the sampled plants, according to Tukey test. However, some different comet classes were found as demonstrated in Figure 1.

Table 2. Comet test results. Mean values (in pixels) \pm standard deviation of DNA fragmentation of $R$. communis cells from data obtained by the program, TriTek CometScore ${ }^{\mathrm{TM}}$ Freeware $v 1.5$ from different areas tested.

\begin{tabular}{lrrrr}
\hline Place & \% Head DNA & \%Tail DNA & Tail Length & Tail moment \\
\hline 1 & $43.98 \pm 37.71$ & $56.02 \pm 37.71$ & $3.95 \pm 7.14$ & $2.66 \pm 4.52$ \\
2 & $51.81 \pm 38.62$ & $48.19 \pm 38.61$ & $3.09 \pm 3.87$ & $2.05 \pm 2.77$ \\
3 & $53.39 \pm 38.38$ & $46.21 \pm 38.34$ & $2.43 \pm 4.60$ & $1.543 \pm 2.79$ \\
4 & $47.64 \pm 35.15$ & $52.36 \pm 35.15$ & $4.55 \pm 5.02$ & $3.26 \pm 4.41$ \\
Control & $67.3 \pm 34.61$ & $32.7 \pm 34.61$ & $2.0 \pm 3.61$ & $1.0 \pm 1.61$ \\
\hline
\end{tabular}

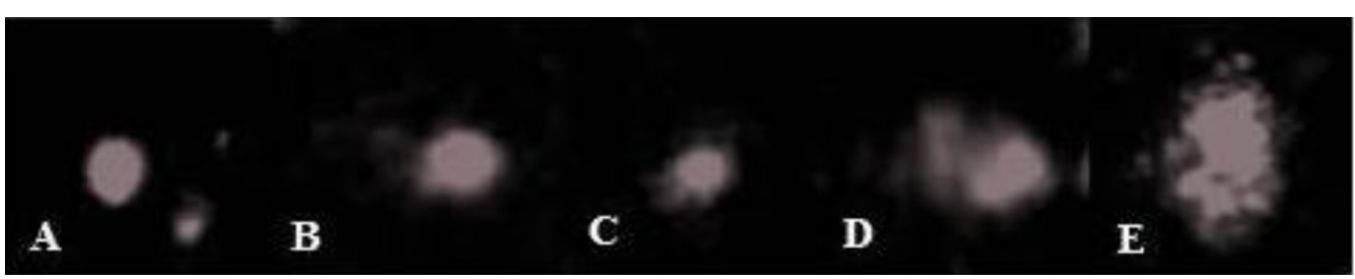

Figure 1. Nucleoids of $R$. communis viewed in Zeiss LSM Image Browser. Following the classification of Schulz et al. (2008) and analyzed by the program TriTek CometScoreTM v 1.5 Freeware. A. Comet Class I; B. Comet Class II; C. Comet III; Class D. Comet Class IV; E. Comet Class V.

\section{Test of peroxidase activity}

Peroxidase activity was shown with greater intensity in plants exposed to air pollution. The control group, located in a place less affected by greenhouse gas emissions, showed no significant activity of peroxidase as demonstrated in Table 3. We were able to observe differences in the activity levels of this class of enzymes between plants exposed to different levels of pollution and verify that the activity was higher in plants located near two major federal highways that bypass the city of Uberlândia (BR 050 and BR 365). 
Table 3. Peroxidase activity in R. communis from different locations in the city of Uberlândia (MG). Absorbance reading at $492 \mathrm{~nm}$ wavelength.

\begin{tabular}{|c|c|c|c|}
\hline Place & Abs $1^{\S}$ & $\mathrm{Abs} 2^{+}$ & Variation \\
\hline 1 & $0.54 \pm 0.16^{b}$ & $0.35 \pm 0.14^{a}$ & Negative ${ }^{\star *}$ \\
\hline 2 & $0.50 \pm 0.16^{b}$ & $0.51 \pm 0.18^{b}$ & Positive $(0.01)^{*}$ \\
\hline 3 & $0.35 \pm 0.11^{\mathrm{a}}$ & $0.34 \pm 0.07^{\mathrm{a}}$ & Positive $(0.01)^{*}$ \\
\hline 4 & $0.50 \pm 0.23^{b}$ & $0.48 \pm 0.22^{\mathrm{b}}$ & Positive $(0.01)^{*}$ \\
\hline Control & $0.40 \pm 0.12^{c}$ & $0.40 \pm 0.12^{\mathrm{c}}$ & Negative ${ }^{* *}$ \\
\hline CV (\%) & 0.74 & 0.84 & - \\
\hline
\end{tabular}

a,b,c Statically significant averages by Tukey test at $5 \%$ significance. ${ }^{*}$ Confirmed presence of peroxidase activity. ${ }^{* *}$ Not possible to verify the peroxidase activity. $\mathrm{CV}=$ coefficient of variation. $\S=$ absorbance reading in the first minute after the reaction; $\dagger=$ absorbance reading of two minutes after the first reading. NS = variation, but not only for peroxidase activity. The change in value obtained allowed for the verification of peroxidase activity, which is determined by changes from 0.01 to 0.02 u.a./min (Oliveira et al., 2008).

\section{Test of pigments determination}

The samples obtained from different sites showed variations in the concentrations of chlorophyll a $(F=9.245 ; P<0.001)$ and chlorophyll b $(F=9.245 ; P<0.001)$, but not carotenoids $(F$ $=1.187 ; P>0.05)$. Significant differences $\left(P_{\text {Tukey at } 5 \%}<0.05\right)$ in the concentration of photosynthetic pigments were found in plants from different zones, as showed in Figure 2. In the control area, plants demonstrated a lower concentration of chlorophyll a $(\mathrm{Ca})$ than the experimental areas.
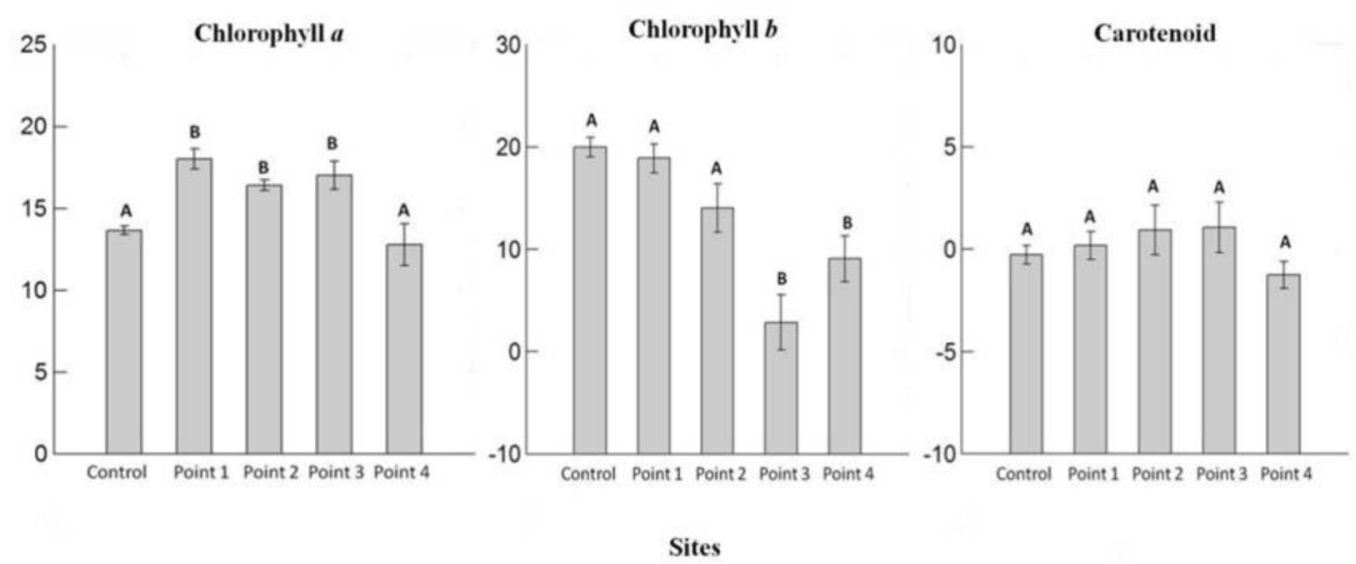

Figure 2. Graphic of pigments concentrations in R. communis leafs in each area of collection. The different letters (A and B) represents statistical differences through Tukey's test at $5 \%$ of significance.

\section{Test buffering capacity $(\mathrm{pH})$}

Ricinus communis showed significant $\left(P_{\text {Tukey at } 5 \%}<0.05\right)$ results after undergoing the buffering capacity test. As shown in Table 4, buffering capacity increased and the leaves from control individuals required less quantity of $\mathrm{HCl}$ to reach determined $\mathrm{pHs}$.

Plants from areas with high pollution levels presented higher buffering potential than the control plants, as determined by Tukey Test. The results indicate that plants in constant exposure to pollution have a higher capacity to control their own physiological system. 
Table 4. Results of buffering capacity test of $R$. communis with the final values of the titration of leaves.

\begin{tabular}{lccr}
\hline Place & $\mathrm{H}^{+}$mmols added & \\
\hline 1 & $1.16^{\mathrm{a}}$ & Inicial pH $^{\mathrm{B}}$ & Final $^{\mathrm{p}} \mathrm{H}^{\mathrm{C}}$ \\
2 & $0.87^{\mathrm{b}}$ & 5.73 & 2.48 \\
3 & $2.07^{\mathrm{a}}$ & 5.48 & 2.47 \\
4 & $0.75^{\mathrm{b}}$ & 5.55 & 2.50 \\
Control & $0.59^{\mathrm{c}}$ & 5.79 & 2.50 \\
\end{tabular}

a,b,c Means differ according to Tukey test at $5 \%$ significance. A. Number of $\mathrm{H}^{+}$moles, calculated from the initial concentration of the acid $(0.01 \mathrm{~N})$. B. pH value of the solution of leaf and water before the addition of $\mathrm{HCl}$. C. final pH value (pre-set, approximately 2.5 ).

To verify whether the plants analyzed are actually being affected by environmental changes in the air, in the soil and in the water, we compared the values of pKa obtained in moment with that of the $\mathrm{pH}$ and pKa are the same. According to Atkins and Jones (2006), each pKa value was related to a substance that can be related to environmental changes, as shown at Table 5 .

\begin{tabular}{|c|c|c|c|c|c|}
\hline \multirow[t]{2}{*}{ Place } & \multirow[t]{2}{*}{$\Delta \mathrm{pKa}$} & \multicolumn{4}{|c|}{ Probable substances based on pKa values } \\
\hline & & Substance $I^{*}$ & Substance $\|^{*}$ & Substance III* & Substance IV* \\
\hline 1 & $\Delta=3.22$ & $\begin{array}{r}\text { Homocystine } \\
(\mathrm{pKa}=2.54)\end{array}$ & $\begin{array}{l}\text { Acetic acid } \\
(\mathrm{pKa}=4.76)\end{array}$ & $\begin{array}{l}\text { Melamin } \\
(\mathrm{pKa}=5.0)\end{array}$ & $\begin{array}{c}\text { Malic Acid } \\
(\mathrm{pKa}=5.09)\end{array}$ \\
\hline 2 & $\Delta=2.31$ & $\begin{array}{l}\text { Tryptophan } \\
(\mathrm{pKa}=2.46)\end{array}$ & $\begin{array}{l}\text { Aminoazobenzene } \\
\quad(\mathrm{pKa}=2.82)\end{array}$ & $\begin{array}{c}\text { Citric acid } \\
(\mathrm{pKa}=3.13)\end{array}$ & $\begin{array}{c}\text { Ascorbic Acid } \\
(\mathrm{pKa}=4.1)\end{array}$ \\
\hline 3 & $\Delta=2.93$ & $\begin{array}{l}\text { Tryptophan } \\
(\mathrm{pKa}=2.46)\end{array}$ & $\begin{array}{l}\text { Homocystine } \\
(\mathrm{pKa}=2.54)\end{array}$ & $\begin{array}{l}\text { Hippuric Acid } \\
(\mathrm{pKa}=3.62)\end{array}$ & $\begin{array}{r}\text { Fumaric Acid } \\
(\mathrm{pKa}=4.49)\end{array}$ \\
\hline 4 & $\Delta=2.60$ & $\begin{array}{l}\text { Homocystine } \\
(\mathrm{pKa}=2.54)\end{array}$ & $\begin{array}{l}\text { Citric acid } \\
(\mathrm{pKa}=3.13)\end{array}$ & $\begin{array}{l}\text { Hippuric Acid } \\
(\mathrm{pKa}=3.62)\end{array}$ & $\begin{array}{l}\text { Melamin } \\
(\mathrm{pKa}=5.0)\end{array}$ \\
\hline Control & $\Delta=3.56$ & $\begin{array}{l}\text { Tryptophan } \\
(\mathrm{pKa}=2.46)\end{array}$ & $\begin{array}{l}\text { Nitrous Acid } \\
(\mathrm{pKa}=3.15)\end{array}$ & $\begin{array}{l}\text { Melamin } \\
(\mathrm{pKa}=5.0)\end{array}$ & $\begin{array}{l}\text { Malic Acid } \\
(\mathrm{pKa}=5.09)\end{array}$ \\
\hline
\end{tabular}

$\Delta \mathrm{pKa}=$ pKa values (maximum and minimum) calculated by Henderson-Hasselbach equation. Substances I, II, III and IV were determined in order to each plateau observed in the buffering test graph.

\section{DISCUSSION}

The comet assay revealed that the genetic material of $R$. communis was not damaged by pollutants. All plants exposed to different levels of pollution show the same type of DNA fragmentation, further reinforcing the benefit of using of this plant in polluted environments as a bioindicator. The heavy vehicular traffic and the large number of industries in the city of Uberlândia (MG, Brazil) are the main cause of atmospheric pollution in this area. This was shown to cause physiological changes in exposed plant matter, making peroxidase levels an interesting criterion to identify pollution caused stress in castor bean leaves (Bakiyaraj and Ayyappan, 2014).

In the control area, plants demonstrated lower concentrations of chlorophyll a $(\mathrm{Ca})$ than in the areas of varying pollution due to the higher concentrations of $\mathrm{NO}_{2}$. When $\mathrm{NO}_{2}$ is absorbed by leaves, it becomes a precursor to chlorophyll or it can even stimulate chloroplasts to produce more chlorophyll. Different results for chlorophyll a $(\mathrm{Ca})$ were obtained, and the control plants showed a higher concentration of chlorophyll $b(\mathrm{Cb})$ in the study sites as well, contrary to that found in literature. According to Kammerbauer and Dick (2000) when there is an increase of chlorophyll b it probably occurred an increase with chlorophyll a too. The carotenoids $(x+c)$ showed no variation 
in concentration, indicating that there is no change in individuals exposed to pollution. Carotenoids are accessory pigments and are present at lower concentrations as compared to the chlorophyll pigments. Therefore, it is possible that pollution can select physiological changes that promote fitness for the new environmental situation with mechanisms of resistance to stress preserving and improving its performance (Kammerbauer and Dick, 2000).

In the future, a complement to the present study would be analyzes with gas-mass chromatography and high performance liquide chromatography (HPLC). Tryptophan is a common amino acid in plants; it is an essential component of protein and takes part in the reactions of various substances such as indole acetic acid (IAA) a plant growth hormone (Dutra et al., 2002). Homocystine is a chemical compound derived from the oxidation of homocysteine, which is an important trace amino acid with regulatory functions in methionine metabolism. Aminoazobenzene is a type of azo dye, and a potent toxicological compound, used in the dyeing industry and frequently leached into the environment.

Malate is synthesized during the carboxylation of phosphoenolpyruvate in the guard cells of stomata in plant tissues, and plays an important role in the cell osmoregulation. The presence of ascorbic acid was observed in high concentrations as ascorbate, which is considered an antioxidant and a substrate for peroxidase activity, being one of the main metabolizers found in plants. The melamine is produced from urea and generally used to produce fertilizers.

Three substances are related to the citric acid cycle. Citric acid is an essential compound for the metabolism of any living being. Its citrate conjugate base is one of several components of this cycle. Fumaric acid has a fumarate conjugate base, which is another intermediary. The acetic acid ionized, as acetate, form the acetyl coenzyme A (acetyl CoA), an essential molecule for this cycle (Nelson et al., 2006).

Nitrous acid is formed by a reaction between nitrogen monoxide (NO) and water in the atmosphere, can be inferred inside the cells. The presence of this acid in the sampled plants indicates NO is absorbed by leaves in greater concentrations (Nelson et al., 2006).

The results of different tests obtained in this study favor using castor bean as an environmental bioindicator. This plant experiences many physiological changes induced by environmental conditions, which can be assessed chemically and genetic evaluation tools. The main parameters observed in the environmental analysis of $R$. communis exposed to pollution were peroxidase activity and the buffering capacity of leaves. Mechanical tests in the field and some studies to verify plant survival in artificial environments with different kinds of pollutants will allow further assessment of the full scope of change in plant physiology and stability, thereby developing its use as bioindicator.

\section{ACKNOWLEDGMENTS}

We would like to thank to Genetics Laboratory team for assisting in bench experiments, and the funding agencies, who supported this work: Fundação de Apoio Universitário (FAU)/ Universidade Federal de Uberlândia, Conselho Nacional de Desenvolvimento Científico e Tecnológico (CNPq) and Fundação de Aamparo à Pesquisa de Minas Gerais (FAPEMIG).

\section{REFERENCES}

Atkins $P$ and Jones $L$ (2006). Princípios de química: questionando a vida moderna e o meio ambiente. Bookman, Porto Alegre, 924 . Ayres M, Ayres Jr M, Ayres DL and Santos AAS (2007). Bioestat: aplicações estatísticas nas áreas das Ciências Biomédicas. 
Versão 5.0. Sociedade Civil Mamirauá - MCT-CNPq, Belém, 324.

Azevedo DMP and Lima EF (2001). O agronegócio da mamona no Brasil. Embrapa Informação Tecnológica, Brasília, 350.

Azevedo DMP, Napoleão EMB, Santos JW, Vieira DJ, et al. (1998). Efeito de população de plantas no rendimento do consórcio de mamona com culturas alimentares. Rev. Bras. Oleag. Fib. 3: 193-202.

Bakiyaraj R and Ayyappan D (2014). Air pollution tolerance index of some terrestrial plants around an industrial area. Int. J. Mod. Res. Rev. 2: 1-7.

Carneiro RMA and Takayanagui AMM (2009). Estudos sobre bioindicadores vegetais e poluição atmosférica por meio de revisão sistemática da literatura. Rev. Bras. C. Amb. 13: 26-44.

Dutra LF, Kersten E and Kachinello JC (2002). Época de coleta, ácido indolbutírico e triptofano no enraizamento de estacas de pessegueiro. Sci. Agric. 59: 327-333.

Freitas PS (2007). Insvestigação do potencial mutagênico do extrato de frutos de Vaccinium corymbosum (Mirtilo) em células de sangue periférico de camundongos Swiss in vivo. Master's Thesis, Universidade José do Rosário Vellano-Unifenas, Alfenas.

Huachaca NSM (2002). Teste do cometa e teste de germinação na detecção do tratamento de alimentos com a radiação ionizante. Master's Thesis, Universidade de São Paulo, São Paulo.

Kammerbauer $\mathrm{J}$ and Dick T (2000). Monitoring of urban traffic emissions using some physiological indicators in Ricinus communis L. plants.Arch. Environ. Contam. Toxicol. 39: 161-166.

Lichtenhauer HK (1987). Chlorophylls and carotenoids: pigments of photosynthetic biomembranes. In: Methods in enzimology (Packer L and Douce RE). Academic Press, London, 350-381.

Nelson DL, Cox M and Lehninger AL (2006). Princípios da Bioquímica. Sarvier, São Paulo.

Oliveira JEZ, Amaral CLF and Casali VWD (2008). Caracterização isoenzimática e atividade de peroxidase em folhas de plantas hiperídrica, intermediária e normal de Bidens pilosa $L$ mantidas in vitro. Ciênc. Agrotec. 32: 32-36.

Popova GM and Moshkin VA (1986). Botanical classification. In: Castor (Moshkin VA, ed.). Amerind Publishing, New Delhi, 11-27.

Santos CV (2004). Regulation of chlorophyll biosynthesis and degradation by salt stress in sunflower leaves. Sci. Hort. 103: 93-99.

Schulz D, Caon T, Mussi CS, Simoes CMO, et al. (2008). Genotoxicity of the antibacterial crude extract from Bacillus amyloliquefaciens R 10 against vero cells. Alim. Nutr. 19: 153-158.

Tice RR, Agurell E, Anderson D, Burlinson B, et al. (2000). The single cell gel /comet assay: guidelines for in vitro and in vivo genetic toxicology testing. Environ. Mol. Mutagen. 35: 206-221. 